\title{
Biochemical Effects of Ethidium Bromide in Micro-organisms
}

\author{
By R. TOMCHICK AND H. G. MANDEL \\ Department of Pharmacology, The George Washington University \\ School of Medicine, Washington, D.C., U.S.A.
}

(Received 31 January 1964)

\begin{abstract}
SUMMARY
Growth of Escherichia coli was partially inhibited by $1.2 \times 10^{-4} \mathrm{M}$ ethidium bromide, a phenanthridinium trypanocide. In the presence of manganese the drug's effect was decreased. During growth in the presence of ethidium, RNA and protein contents were relatively unaffected when comparison was made between experimental and control cultures at similar turbidities; DNA content, on the other hand, was considerably decreased. A differential effect of ethidium on the formation of polynucleotide pyrimidines from labelled uracil and orotic acid was observed. Oxygen uptake continued almost unchanged during growth whether in the presence or absence of drug.

Bacillus cereus was extremely sensitive to the growth-inhibitory action of ethidium $\left(10^{-5} \mathbf{M}\right)$ and morphological changes were observed. Manganese protected the organisms from the drug's actions. RNA and DNA biosynthesis were both suppressed during inhibition of growth to a greater extent than was total protein formation, whereas diaminopimelic acid incorporation into cell wall and oxygen uptake continued almost unaffected. Some evidence was obtained that the pattern of protein synthesis was disturbed.

It was concluded that the drug's actions were species dependent, and that the effect on Escherichia coli resembled that described for a flagellate, while that on Bacillus cereus did not. Evidence for compartmentation of nucleic acid synthesis, as obtained with the drug in tumour cells, was not shown for either micro-organism.
\end{abstract}

\section{INTRODUCTION}

Recent investigations in this laboratory revealed that the trypanocidal phenanthridinium, ethidium bromide (3,8-diamino-5-ethyl-6-phenylphenanthridinium bromide), produced a remarkable inhibition of the incorporation of labelled purines into polynucleotides of Ehrlich ascites cells in vitro, while nucleic acid synthesis continued at an only slightly slowed rate (Kandaswamy \& Henderson, 1962). Since acid-soluble purine nucleotides were formed from the exogenous purines, it was postulated that the drug prevented the incorporation of these purine nucleotides into nucleic acids, while the corresponding compounds from endogenous precursors were condensed into these macromolecules. Additional evidence for this concept of compartmentation of purine nucleotides was the observation that under hypotonic conditions intracellular integrity was not maintained, and the differential effect on nucleic acid synthesis was no longer demonstrable (Kandaswamy \& Henderson, 1963). It was of interest to determine whether the drug could supply 
information on similar compartmentation in micro-organisms. The compound had been shown to inhibit DNA synthesis preferentially in a trypanosomal flagellate (Newton, 1957), and to depress RNA and DNA formation to a greater extent than that of protein in yeast cells (Kerridge, 1958). The drug's actions were therefore evaluated in a Gram-positive organism, Bacillus cereus, and a Gram-negative organism, Escherichia coli, in an effort to uncover dissociation of biosynthetic processes during inhibition of growth. Preliminary reports have been presented (Tomchick \& Mandel, 1962, 1963).

\section{METHODS}

Organisms, media, drug, and labelled compounds. Bacterial studies were made with Bacillus cereus strain $569 \mathrm{H}$ and Escherichia coli strain в (ATCC 11303). The organisms were maintained on sterile nutrient agar slopes at $4^{\circ}$. Bacillus cereus was grown in Casamino acids medium (Smith \& Matthews, 1957) and E. coli was usually grown in $\mathrm{C}$ medium (Roberts et al. 1955).

Ethidium bromide (subsequently called ethidium, see Fig. 1) was furnished by Dr M. R. Gurd of Boots Pure Drug Co., Ltd., Nottingham.

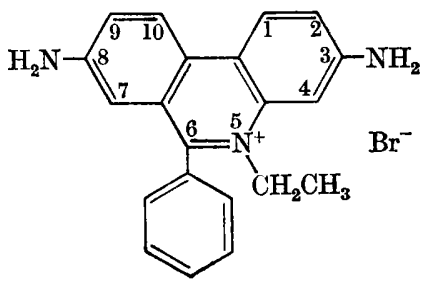

Fig. 1. Ethidium bromide.

The following labelled compounds were used in uptake studies: $8-{ }^{14} \mathrm{C}$-adenine, ${ }_{2-14} \mathrm{C}$-uracil, ${ }^{2-14} \mathrm{C}$-orotic acid, ${ }^{1-14} \mathrm{C}-\mathrm{D}, \mathrm{L}$-valine, $2-{ }^{14} \mathrm{C}-\mathrm{D}, \mathrm{L}-$ methionine, and ${ }^{1-14} \mathrm{C}-\mathrm{D}, \mathrm{L}-$ lysine (from Isotopes Specialties Co., Inc., Burbank, Calif.); ${ }^{2-14} \mathrm{C}-$ glycine, from

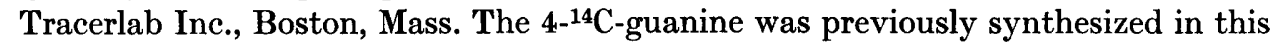
laboratory (Mandel \& Carló, 1953) and ${ }^{3} \mathrm{H}$-diaminopimelic acid $\left({ }^{3} \mathrm{H}-\mathrm{DAP}\right)$ was obtained from Dr J. L. Strominger (Washington University, St Louis, Mo.).

Growth and uptake studies. Sterile medium (50 ml.) was inoculated from an agar slope and the culture allowed to incubate overnight at $37^{\circ}$. After centrifugation the pellet was resuspended and shaken in a gyratory shaker at $37^{\circ}$ until a turbidimetric reading $\left(\mathrm{OD}_{620}\right)$ of 0.400 at $620 \mathrm{~m} \mu$ (Beckman Spectrophotometer, Model DU) was reached. At this wavelength interference from light absorption by ethidium was minimal. The bacterial suspension was then diluted with fresh medium to $\mathrm{OD}_{620} 0 \cdot 150$ and grown again. At $\mathrm{OD}_{620}, 0 \cdot 200$ ethidium bromide and radioactive precursors were added and incubation continued.

For rapid determination of radioactive precursors in various chemical fractions of bacteria, organisms were selectively extracted by reagents, followed by filtration through a collodion membrane. Distribution into protein, DNA, and RNA was calculated by difference (Roodyn \& Mandel, 1960a). Generally, 2 ml. samples of exponentially growing bacterial cultures were sampled at $\mathrm{OD}_{620}$ readings of approximately $0 \cdot 200,0 \cdot 250,0 \cdot 300,0 \cdot 350,0 \cdot 400$. These samples were placed in tubes 
containing $2 \mathrm{ml} .10 \%(\mathrm{w} / \mathrm{v})$ trichloroacetic acid (TCA) solution and allowed to stand 15-30 min. in the cold. The material was then filtered through a coarse filter membrane (Type A, Schleicher and Schuell Co.) and washed twice with $1 \%$ TCA. The residue on the membrane represented the acid-insoluble fraction (proteins, nucleic acids, etc.) and the filtrate the acid-soluble fraction.

To determine the incorporation of precursors into the protein portion, samples of culture were mixed with TCA as before and were heated at $100^{\circ}$ for $30 \mathrm{~min}$. This treatment solubilized polynucleotides but not proteins. The protein fraction was recovered quantitatively on the filter.

To estimate DNA of Bacillus cereus, a $5 \mathrm{ml}$. sample of the original bacterial suspension was treated with $1 \mathrm{ml}$. of $3 \mathrm{~N}-\mathrm{KOH}$ and allowed to stand overnight at room temperature. DNA remained insoluble and was recovered quantitatively after filtration of the KOH hydrolysate, while RNA was hydrolysed and solubilized during the process, and was removed during the filtration (Roodyn \& Mandel, $1960 a$ ). Filters were attached to aluminium planchets with rubber cement and, when dry, counted in a gasflow proportional counter. The total radioactivity was estimated directly for ${ }^{14} \mathrm{C}$-labelled compounds which were plated essentially at infinite thinness. In the case of soft radiation from ${ }^{3} \mathrm{H}-\mathrm{DAP}$ the relative total activity was computed by multiplying the specific activity values (obtained from counting the filters directly) by the turbidity reading $\left(\mathbf{O D}_{620}\right)$ of the bacterial suspension, a function of cell mass (Alpen \& Mandel, 1960). To show reproducibility of results, duplicate or triplicate samples were taken of control and drug-treated cultures at the various turbidimetric readings.

Separation of $R N A$ pyrimidine nucleotides. Twenty-five ml. samples of bacterial suspensions were centrifuged at $17,300 \mathrm{~g}$ for $10 \mathrm{~min}$. and the resulting pellet extracted with $80 \%(\mathrm{v} / \mathrm{v})$ ethanol in water at $80-85^{\circ}$ for about $1 \mathrm{~min}$. Upon cooling, the supernatant ethanolic extract was decanted. A drop of $\mathrm{N}-\mathrm{KOH}$ was added to the residue to hydrolyse the $\mathrm{RNA}$ to mononucleotides (overnight, $25^{\circ}$ ). The samples were then adjusted to $\mathrm{pH} 4$ with $10 \%$ perchloric acid (PCA) at $0^{\circ}$, centrifuged in the cold, and the supernatant fluid subjected to paper electrophoresis at $\mathbf{p H ~} 3 \cdot 5$ to separate the mononucleotides (Markham \& Smith, 1952). Molar activities were calculated from radioactivity and ultraviolet extinction coefficients of uridylic acids.

Chemical determination of proteins, $R N A$ and $D N A$. One ml. samples of growing cultures were mixed with an equal volume of $10 \% \mathrm{TCA}$ and centrifuged. The pellet was then analysed for protein, using the method of Oyama \& Eagle (1956). Bovine serum albumin (Armour Pharmaceutical Co.) was used as the standard.

RNA was determined by the colorimetric method of Schneider (1945). One ml. samples of bacterial suspension were centrifuged, washed with saline, and mixed with $5 \%$ PCA. After heating for $15 \mathrm{~min}$. at $100^{\circ}$ to hydrolyse polynucleotides, $1 \mathrm{ml}$. of the filtrate was reacted with the ferric chloride orcinol reagent. Purified yeast nucleic acids (Nutritional Biochemical Co.) served as standard.

Ten ml. samples of bacterial suspension were taken for DNA analysis (Burton, 1955). Salmon sperm DNA (Nutritional Biochemical Corp.) was used as standard.

Manometric experiments. One ml. of bacterial suspension was placed in manometric flasks and oxygen uptake measured by the usual manometric procedure of Umbreit, Burris \& Stauffer (1957). 


\section{RESULTS}

\section{Effect of ethidium on growth}

Ethidium bromide produced inhibition of growth of Bacillus cereus at much lower concentrations than with Escherichia coli. Although the two organisms were usually grown in different media, ethidium bromide was equally inhibitory to $E$. coli when grown in either medium, indicating that the difference in susceptibility to the drug

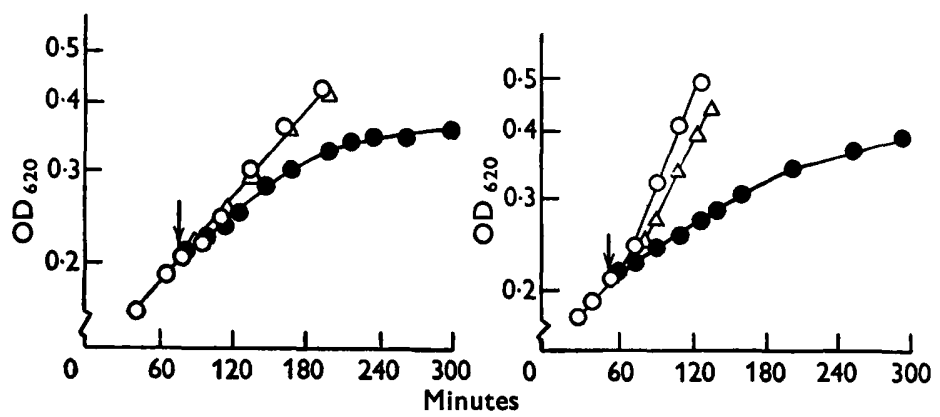

Fig. 2. Growth measured turbidimetrically at $620 \mathrm{~m} \mu$, in the presence of ethidium bromide added at arrow. Left, Escherichia coli: Control, $\bigcirc-O$; ethidium bromide 0.025 mM, $\triangle \longrightarrow \triangle$; and $0.12 \mathrm{~mm},-\longrightarrow$. Right, Bacillus cereus: Control, $\mathrm{O}-\mathrm{O}$; ethidium bromide $5 \mu \mathrm{M}, \triangle \longrightarrow \triangle$; and $10 \mu \mathrm{M},-$

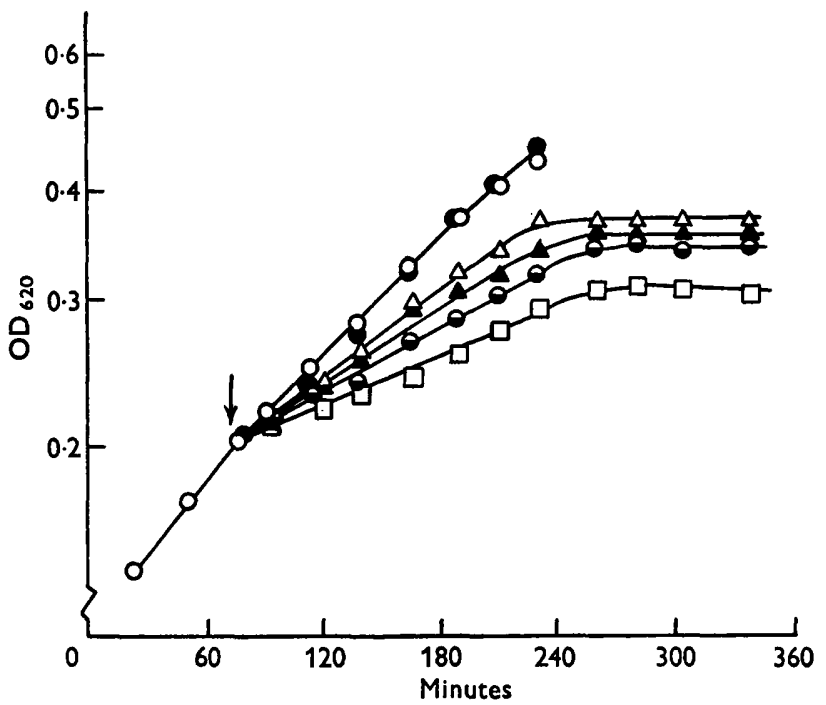

Fig. 3. Antagonism of ethidium bromide-induced growth inhibition (0.12 mm) of Escherichia coli by manganese; ethidium bromide and manganese added at arrow. Control,

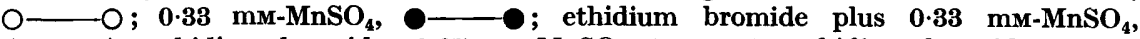
$\triangle-\triangle$; ethidium bromide $+0.07 \mathrm{mM}_{-\mathrm{MnSO}_{4}, \Delta-\triangle}-\mathbf{\Delta}$; ethidium bromide $+7 \mu \mathrm{M}-$ $\mathrm{MnSO}_{4}, \ominus-\odot$; ethidium bromide only, $\square-\square$.

was related to the organisms. Marked slowing of growth of $B$. cereus was observed at $10^{-5} \mathrm{M}$-ethidium, whereas a corresponding concentration of $1.2 \times 10^{-4} \mathrm{M}$ was necessary for $E$. coli. The characteristic pattern of the drug's effect on growth is recorded in 
Fig. 2. With $E$. coli the onset of inhibition occurred more gradually than with $B$. cereus, but only with $\boldsymbol{E}$. coli did growth cease altogether, as measured turbidimetrically. Organisms were still viable upon subculturing after exposure for $3 \mathrm{hr}$ to the drug.

Associated with the inhibition of growth were some morphological changes of the organisms. Escherichia coli appeared to be slightly larger and thicker after drug treatment, while Bacillus cereus showed major modifications in structural morphology. Cell contents were disorganized and less aggregated, and the cells, which appeared more granular, were elongated in shape, upon Gram staining ( $\mathrm{Pl}$. 1, fig. 1-4). A characteristic colour shift was noted a few minutes after the addition of the orange-red drug, and the bacterial suspension became pink.

Growth inhibition by ethidium depended on the concentration of manganese ion in the medium, and could be partially overcome in both microbial systems at a molar concentration twice that of the drug. Figure 3 shows the effect of different concentrations of the metal ion on the drug-induced growth inhibition of Escherichia coli. Antagonism of growth inhibition by manganese became less pronounced when the interval between the addition of drug and $\mathrm{Mn}^{2+}$ was increased. Occasionally guanine produced antagonism of the inhibition of growth in Bacillus cereus.

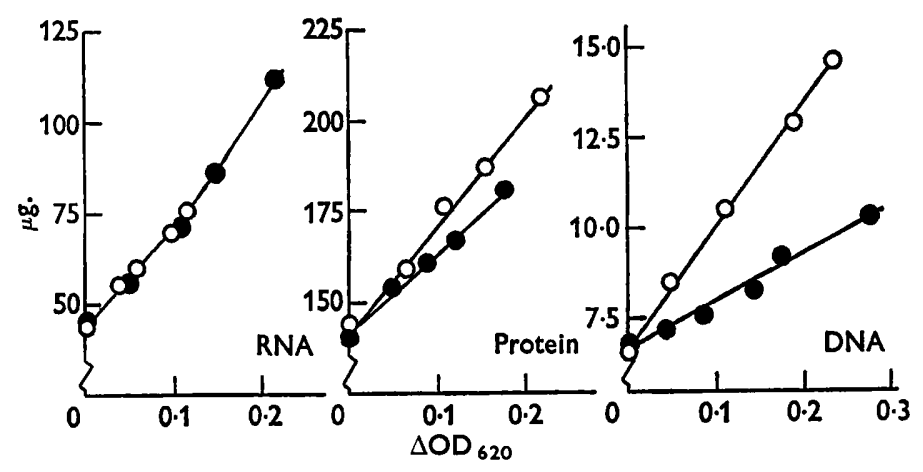

Fig. 4. Effect of ethidium bromide on content of RNA, protein, and DNA of Escherichia coli in organisms/ml. suspension. Colorimetric assays described in Methods. Control, $\mathrm{O} \longrightarrow-\mathrm{O} ; 0.12$ mM-ethidium bromide, $-\longrightarrow$ -

\section{Effects on biosynthesis}

Escherichia coli. Figure 4 shows that for the same change in turbidity reading of the culture, RNA synthesis was unaffected by drug treatment, whereas only a very slight depression of protein biosynthesis was observed. On the other hand, DNA synthesis was significantly decreased during inhibition of growth. Studies with labelled precursors were usually in agreement with the measurements of content of the major constituents. Thus, ${ }^{8-14} \mathrm{C}$-adenine uptake into nucleic acids (mainly RNA) was essentially unaffected, as was that of ${ }^{2-14} \mathrm{C}$-methionine, ${ }^{2-14} \mathrm{C}$-lysine, or ${ }^{1-14} \mathrm{C}$-valine into TCA-insoluble protein.

An unexpected finding was the differential effect of ethidium on the incorporation of ${ }^{2-14} \mathrm{C}$-uracil and ${ }^{2-14} \mathrm{C}$-orotic acid into pyrimidines of RNA. Figure 5 indicates that more uracil was used for nucleic acid synthesis in the presence of ethidium than 
in its absence, results which were confirmed by measurement of molar radioactivities of isolated uridylic and cytidylic acids from RNA (Table 1). (During these studies, the separation of mononucleotides following $\mathrm{KOH}$ digestion of cell residues revealed the presence of a strongly fluorescent compound which was identical in its electrophoretic mobility and $\boldsymbol{R}_{\boldsymbol{F}}$ to ethidium.) The uptake of orotic acid into polynucleotide pyrimidines, however, was sharply curtailed.

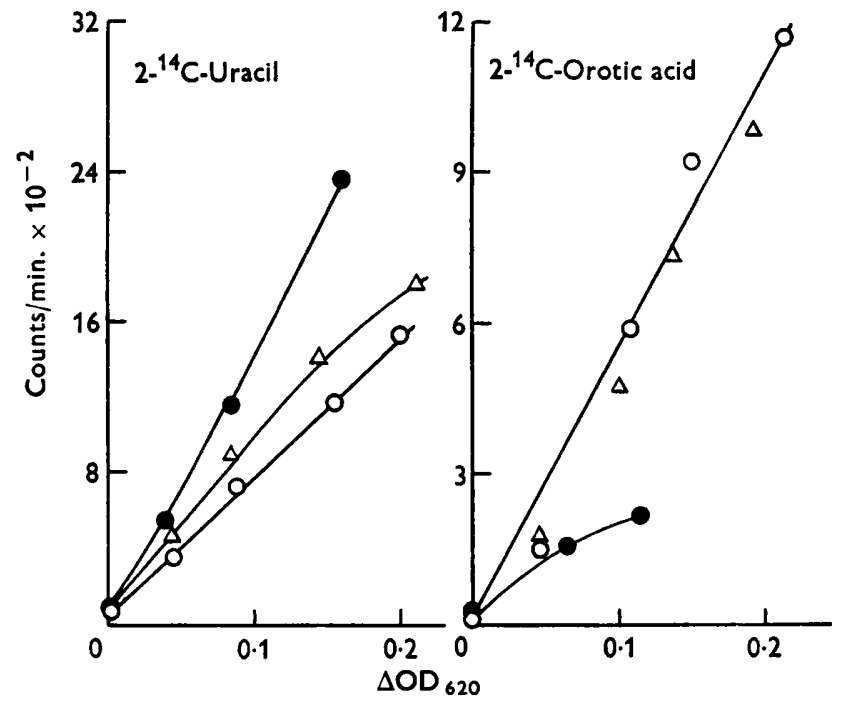

Fig. 5. Uptake of radioactivity from $2-{ }^{14} \mathrm{C}$-uracil and ${ }^{2-14} \mathrm{C}$-orotic acid into the cold-TCA insoluble fraction of a $2 \mathrm{ml}$. culture sample of Escherichia coli. Control culture, $\mathrm{O}----\mathrm{O}$; ethidium bromide $0.025 \mathrm{~mm}, \triangle-\longrightarrow \triangle ; 0.12 \mathrm{~mm}$,

\section{Table 1. Radioactivity of RNA mononucleotides from Escherichia coli grown} with ethidium bromide in the presence of $2-{ }^{14} \mathrm{C}$-uracil

The control and $0.025 \mathrm{~mm}$ concentrations have been corrected to the final culture turbidity of the $0 \cdot 12 \mathrm{~mm}$ concentration.

Expt. 1.

Ethidium bromide (mM)

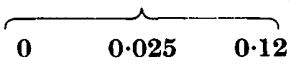

Counts/min./mmole

Cytidylic acid

Uridylic acid

$\begin{array}{lll}1298 & 2431 & 3614 \\ 1460 & 2397 & 3414\end{array}$

Expt. 2.

Ethidium bromide (mM)

$\begin{array}{lll}0 & 0.025 & 0.12 \\ \text { Counts } / \text { min./mmole } & \text { mo } \\ 4545 & 5376 & 6815 \\ 4893 & 5638 & 8300\end{array}$

Bacillus cereus. In contrast to the results with Escherichia coli, RNA content of $B$. cereus was decisively decreased by ethidium treatment, whereas the effect on total protein biosynthesis again was quite small. DNA content also was decreased (Fig. 6).

The incorporation of various labelled precursors is shown in Fig. 7. The utilization of adenine for RNA, and also DNA synthesis, was sharply decreased immediately after treatment with ethidium, although eventual recovery from this effect did occur. Similar results were obtained in studies with labelled hypoxanthine, uracil 
and, to a lesser extent, orotic acid. The very slight depression of the incorporation of

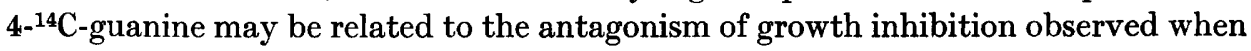
this purine was added.

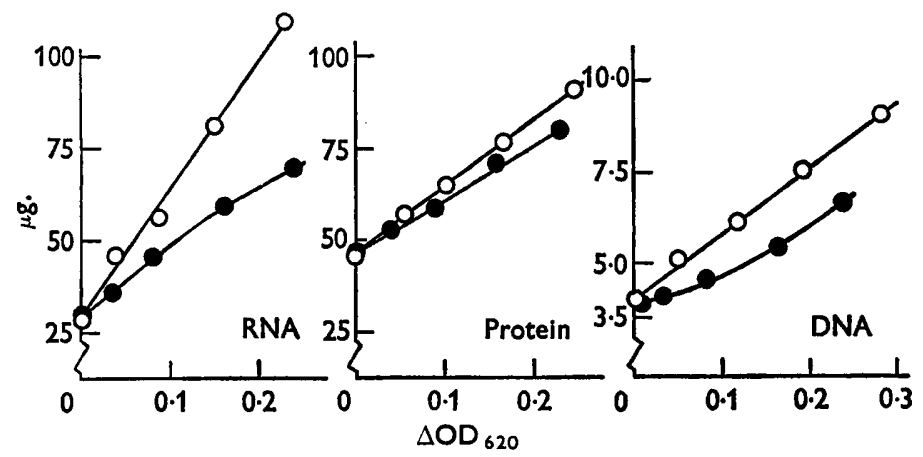

Fig. 6. Effect of ethidium bromide on content of RNA, protein, and DNA of Bacillus cereus in organisms $/ \mathrm{ml}$. of suspension. Colorimetric assays described in Methods. Control, $\mathrm{O}-\mathrm{O} ; 10 \mu \mathrm{M}$-ethidium bromide,
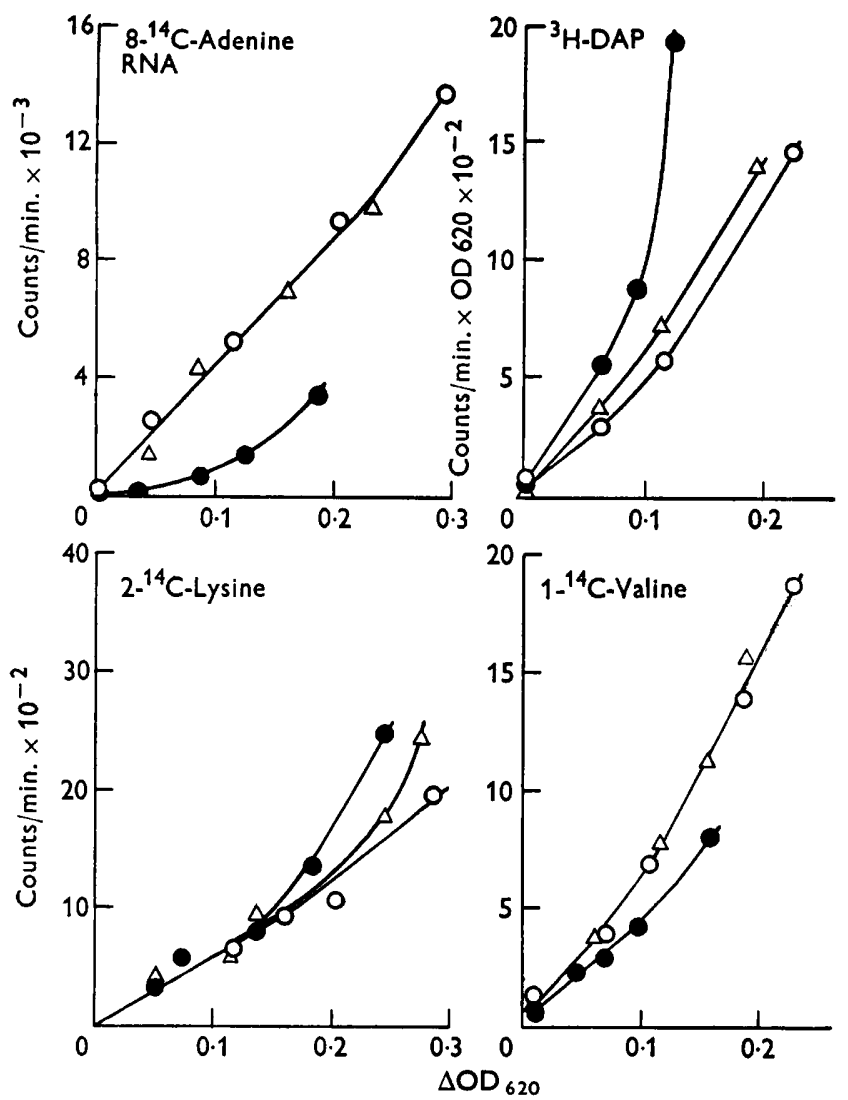

Fig. 7. Uptake of radioactivity from various precursors into the cold-TCA insoluble fraction of Bacillus cereus. Control, $\mathrm{-}-\mathrm{O}$; ethidium bromide $5 \mu \mathrm{M}, \triangle-\triangle \triangle$; $10 \mu \mathrm{M}$, Top left: ${ }^{8-14} \mathrm{C}$-adenine into RNA; top right: ${ }^{3} \mathrm{H}-\mathrm{DAP}$ into cell wall; bottom left : ${ }^{2-14} \mathrm{C}$-lysine into protein; bottom right: $1-{ }^{14} \mathrm{C}$-valine into protein. 
Diaminopimelic acid, a characteristic component of the cell wall of various microorganisms (Work, 1951), has been used as an index to measure the formation of that constituent (Roodyn \& Mandel, 1960b). The increased incorporation of that precursor for the same change in culture turbidity in the presence of ethidium implies that more cell wall was being formed in relation to the total mass of organism synthesized. When plotted on a rate basis, the uptake of diaminopimelic acid continued at essentially the same rate as before the addition of ethidium.

Considerable variation was observed in the uptake of individual amino acids into bacterial protein (Fig. 7). Thus, the incorporation of lysine was increased, that of valine decreased, and that of methionine unchanged by treatment with ethidium, comparisons being made at similar turbidity of the cultures. It would appear that ethidium disrupted the normal pattern of protein biosynthesis.

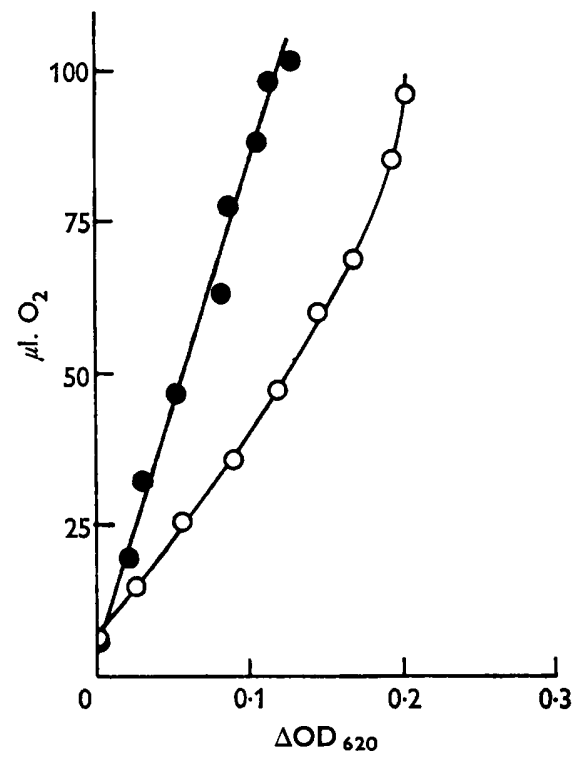

Fig. 8. Uptake of oxygen by cultures of Escherichia coli growing in the presence and absence of ethidium bromide. Control, $\mathrm{O}-\mathrm{O} ; 0.12 \mathrm{~mm}$-ethidium bromide,

\section{Effects on oxygen consumption}

Ethidium bromide had little effect on oxygen consumption in comparison to its depressant actions on growth and biosynthesis. With Escherichia coli, the rate of oxygen consumption was essentially unaffected by drug treatment; since growth was slowed, the utilization of oxygen for similar turbidimetric changes was increased in the presence of the drug (Fig. 8). With Bacillus cereus also, but to a somewhat lesser extent, oxygen consumption was greater for similar increments of culture turbidity during inhibition by ethidium. These results suggest the possibility that ethidium may also be capable of uncoupling oxidative phosphorylation. 


\section{DISCUSSION}

Certain major differences in the effect of ethidium bromide on the two strains of micro-organisms used were apparent. Growth of Bacillus cereus was inhibited at about one-twelfth the concentration of ethidium needed with Escherichia coli. This observation is in agreement with a previous report (Brownlee et al. 1950) that Gram-positive micro-organisms are more readily affected by phenanthridinium compounds than Gram-negative organisms. In addition, the extensive morphological changes probably are related to changes in the ribosome-containing chromophilic granules in cytoplasm of trypanosomes treated with a related drug, dimidium (the 5-methyl analogue of ethidium), as first reported by Ormerod (1951).

Various distinctions in the biochemical actions of ethidium on the two organisms were also noted. During inhibition of growth of Escherichia coli, the most noticeable change was a sharp decrease in DNA content while the overall effects on RNA and protein biosynthesis were minor. The system resembles that of the trypanosomal flagellate Strigomonas oncopelti described by Newton (1957), where the most pronounced drug effect was also directed at DNA synthesis. The differential effect of ethidium on the formation of tumour cell polynucleotides in vitro from exogenous and endogenous precursors (Kandaswamy \& Henderson, 1962) was not demonstrable in the $E$. coli system since neither ${ }^{14} \mathrm{C}$-adenine uptake nor RNA content were affected during growth to the same cultural turbidity in the presence or absence of the drug.

It is difficult to explain the observed effects of ethidium on pyrimidine biosynthesis in Escherichia coli. The increased utilization of exogenous uracil, in contrast to that of orotic acid (Fig. 5), is probably unrelated to endogenous nucleic acid pyrimidine biosynthesis, which was not affected (Fig. 4). Neither of the two precursors is required for growth, although both compounds can serve to form nucleic acid pyrimidines. Although several possible alternatives exist, compartmentation of pyrimidine pools may account for the differential actions by ethidium on the incorporation of the precursors.

Inhibition of the Bacillus cereus system by ethidium resulted in greater depression of nucleic acid biosynthesis than that of protein. Cell wall biosynthesis, as observed during growth inhibition with 8-azaguanine (Roodyn \& Mandel, 1960 b) and chloramphenicol (Mandel \& Altman, 1961) in the same bacterial system, continued at almost the same rate as before the addition of ethidium. The effects on $B$. cereus resemble those on the yeast, Saccharomyces carlsbergensis, as described by Kerridge (1958), who observed a preferential inhibition of nucleic acid biosynthesis by ethidium in comparison with its effect on total protein formation. With B. cereus, ethidium depressed ${ }^{14} \mathrm{C}$-adenine uptake into nucleic acids and endogenous RNA synthesis to approximately the same extent, thus differing from the results of Kandaswamy $\&$ Henderson (1962) with tumour cells, who reported the almost complete suppression of adenine incorporation by ethidium in contrast to a relatively minor inhibition of nucleic acid formation from endogenous precursors such as ${ }^{14} \mathrm{C}$-glycine.

The differential effects of ethidium on the utilization of various amino acids by Bacillus cereus is of interest. The amino acids chosen were precursors of protoplasmic protein rather than of cell wall (Roodyn \& Mandel, 1960 b). The results obtained suggest a major derangement of protein biosynthesis. It is possible that particular proteins are made in abnormal quantities, or that the ethidium changed the amino 
acid composition of certain proteins. In this connexion, the inhibition by ethidium of lytic enzyme synthesis in a strain of $\boldsymbol{B}$. subtilis may be of interest, although the specificity of this effect on protein formation and inhibition of all processes of cellular growth is not clear (Richmond, 1959).

The interaction of phenanthridiniums closely related to ethidium bromide with nucleic acids, particularly DNA, was reported (Brownlee et al. 1950; Seaman \& Woodbine, 1955). In the present experiments ethidium was bound extensively to bacteria, and was usually recoverable following $\mathrm{KOH}$ digestion of the organisms and separation of mononucleotides. The similarity in structure of ethidium to acridine derivatives, such as acriflavin, acridine orange, and proflavin, and the reported binding of the latter group of drugs to polynucleotides, certainly suggest similarities in action. Ethidium (Elliott, 1963), like the acridines (Leith, 1963), is believed to form a complex with DNA, thereby interfering with DNA polymerase activity. Although little information has been reported on the effect of the acridines on biosynthetic processes, it is believed that the intercalation of these drugs in the DNA molecule (Lerman, 1963) is responsible for their growth inhibitory and mutagenic properties. A similar possibility should be considered with ethidium bromide. Another mutagenic drug, 5-bromouracil (Michaelson \& Mandel, 1962), which was studied in an Escherichia coli system, was shown to inhibit DNA formation, to be incorporated into bacterial DNA, and to produce effects indicative of disruption of the pattern of protein biosynthesis.

The mechanism of reversal of the drug's effects by manganese is unclear. Since it is doubtful that ethidium chelates the metal, perhaps the divalent cation interferes with the drug's binding to polynucleotides or ribosomes. In the two bacterial systems requiring different concentration of drug for inhibition of growth, the effective concentration of $\mathrm{Mn}^{2+}$ was found to be related to that of ethidium. The reversing effect of guanine may be more closely related to the observed action of nucleic acids in preventing the drug's actions, perhaps by binding the drug before it has a chance to act in the cell.

This work was done in partial satisfaction of requirements for the Master of Science degree at the Department of Pharmacology, The George Washington University, in 1963. The research was supported in part by Public Health Service Research Grant (AI-04264) from the National Institute of Allergy and Infectious Diseases, and in part by a Public Health Service Grant (5T1-GM-26) from the Division of General Medical Sciences, Public Health Service, Bethesda, Maryland, U.S.A.

\section{REFERENCES}

Alpen, E. L. \& Mandel, H. G. (1960). A rapid assay method for tritium in bacterial cells. Biochim. biophys. Acta, 43, 317.

Brownlee, G., Goss, M. D., Goodwin, L. G., Woodbine, M. \& Walls, L. P. (1950). The chemotherapeutic action of phenanthridine compounds. Part. I. T. congolense and $T$. rhodesiense. Br. J. Pharmac. Chemother. 5, 261.

Burton, K. (1955). The relation between the synthesis of DNA and synthesis of protein in the multiplication of bacteriophage T-2. Biochem.J. 61, 473.

Elliott, W. H. (1963). The effects of antimicrobial agents on deoxyribonucleic acid polymerase. Biochem. J. 86, 562 . 
Kandaswamy, T. S. \& Henderson, J. F. (1962). Intracellular differentiation of purine ribonucleotides derived from endogenous and exogenous sources. Biochim. biophys. Acta, 61, 86.

Kandaswamy, T. S. \& Henderson, J. F. (1963). Alteration of the biochemical effects of ethidium bromide by exposure of cells to hypotonic media. Nature, Lond. 199, 807 .

KERRIDGE, D. (1958). The effect of actidione and other antifungal agents on nucleic acid and protein synthesis in Saccharomyces carlsbergensis. J. gen. Microbiol. 19, 492.

LEITH, J. D., Jr. (1963). Acridine orange and acriflavin inhibit deoxyribonuclease action. Biochim. biophys. Acta, 72, 643.

Lerman, L. S. (1963). The structure of the DNA-acridine complex. Proc. nat. Acad. Sci., Wash. 49, 94.

Mandel, H. G. \& Altman, R. L. (1961). Some effects of chloramphenicol on biosynthesis in Bacillus cereus. J. Pharmac. exp. Therap. 133, 151.

MaNdel, H. G. \& Carló, P. (1953). Incorporation of guanine into nucleic acids of tumorbearing mice. J. biol. Chem. 201, 335.

MarkhaM, R. \& Smith, J. D. (1952). The structure of ribonucleic acids. I. Cyclic nucleotides produced by ribonuclease and by alkaline hydrolysis. Biochem. J. 52, 552 .

Michaelson, I. A. \& Mandel, H. G. (1962). Some effects of 5-bromouracil on a thyminerequiring mutant of Escherichia coli. Biochem. Pharmacol. 11, 243.

Newton, B. A. (1957). The mode of action of phenanthridines: the effect of ethidium bromide on cell division and nucleic acid synthesis. J. gen. Microbiol. 17, 718.

Ormerod, W. E. (1951). A study of basophilic inclusion bodies produced by chemotherapeutic agents in trypanosomes. Brit.J. Pharmacol. 6, 334.

Oyama, V. I. \& EaGLE, H. (1956). Measurement of cell growth in tissue culture with a phenol reagent (Folin-Ciocalteau). Proc. Soc. exp. Biol., N.Y. 91, 305.

Richmond, M. H. (1959). Effect of inhibitors on lytic enzyme synthesis by Bacillus subtilis. Biochim. biophys. Acta, 34, 325.

Roberts, R. B., Abelson, P. H., Cowie, D. B., Bolton, E. T. \& Britten, R. J. (1955). Studies of biosynthesis in E. coli. Publ. Carneg. Instn, Wash. no. 607.

Roodyn, D. B. \& MANdel, H. G. (1960a). A simple membrane fractionation method for determining the distribution of radioactivity in chemical fractions of Bacillus cereus. Biochim. biophys. Acta, 41, 80.

Roodyn, D. B. \& MANDEL, H. G. (1960b). The differential effect of 8-azaguanine on cell wall and protoplasmic protein synthesis in Bacillus cereus. J. biol. Chem. 235, 2036.

Schneider, W. C. (1945). Phosphorus compounds in animal tissue. I. Extraction and estimation of desoxypentose-nucleic acid and of pentose nucleic acid. J. biol. Chem. 161, 293.

Seaman, A. \& Woodbine, M. (1955). The therapeutic index of chemotherapeutic agents. The effect of nucleic acid on dimidium bromide. J. appl. Bact. 18, 397.

Smith, J. D. \& MAtThews, R. E. F. (1957). The metabolism of 8-azapurines. Biochem. J. 66, 323.

Tomchick, R. \& Mandel, H. G. (1962). The growth inhibition of ethidium bromide in Bacillus cereus. Proc. Am. Assoc. Cancer Res. 3, 368.

Tomchick, R. \& MANDEL, H. G. (1963). Effects produced by ethidium bromide in Bacillus cereus and Escherichia coli. Abstr. 3rd Intersci. Conf. antimicrob. Agents Chemother. p. 64.

Umbreit, W. W., Burris, R. H. \& Stauffer, J. F. (1957). Manometric Techniques, 3rd ed. Minneapolis: Burgess Publishing Company.

Work, E. (1951). The isolation of $\alpha, \epsilon$-diaminopimelic acid from Corynebacterium diphtheriae and Mycobacterium tuberculosis. Biochem. J. 49, 17. 


\section{EXPLANATION OF PLATE}

Micrographs of Escherichia coli and Bacillus cereus all at the same magnification.

Fig. 1. Escherichia coli control

Fig. 2. E. coli grown in $0 \cdot 12 \mathrm{~mm}$ ethidium bromide.

Fig. 3. Bacillus cereus control.

Fig. 4. B. cereus grown in $10 \cdot 0 \mu \mathrm{M}$ ethidium bromide. 
Journal of General Microbiology, Vol. 36, No. 2

Plate 1
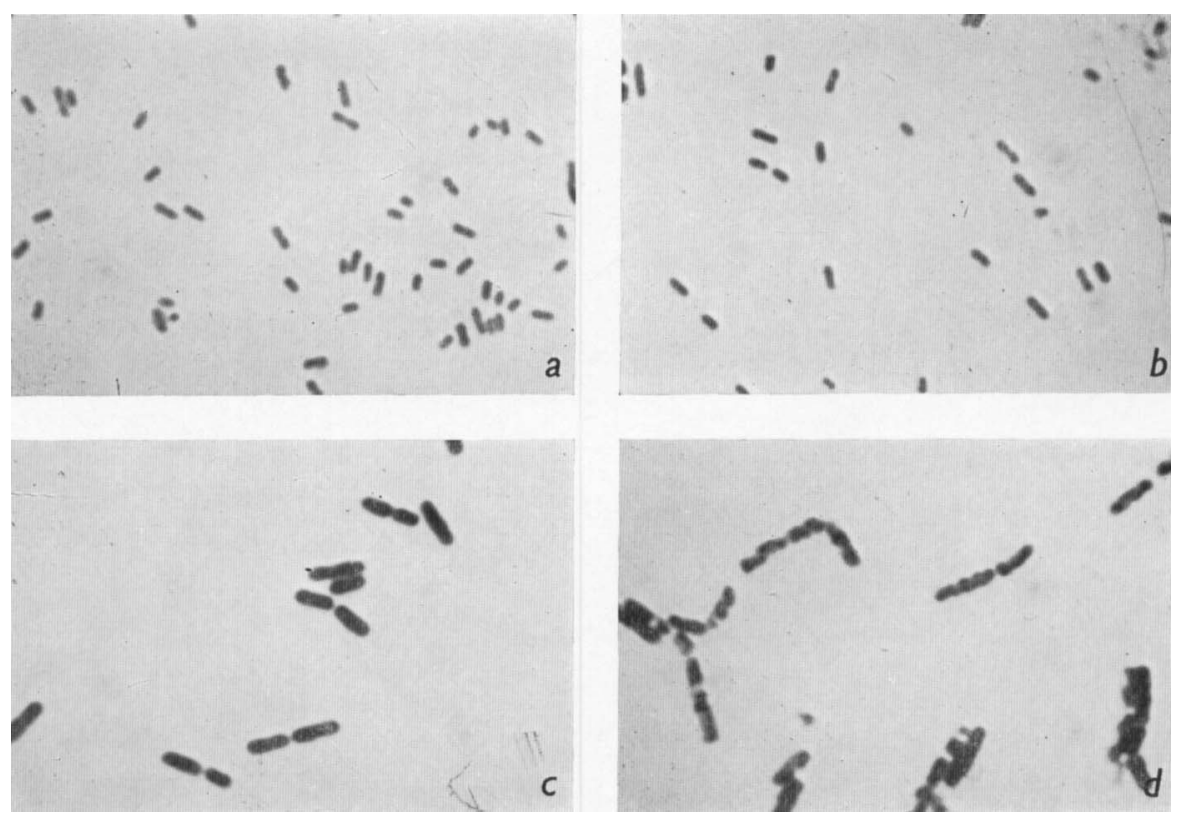

R. 'TOMCHICK AND H. G. MANDEL

(Facing $p .236$ ) 